The importance of customer

\title{
expectations: An analysis of CSR in container shipping
}

Tang, Lijun

http://hdl.handle.net/10026.1/12721

10.1007/s10551-018-4062-4

Journal of Business Ethics

Springer Verlag

All content in PEARL is protected by copyright law. Author manuscripts are made available in accordance with publisher policies. Please cite only the published version using the details provided on the item record or document. In the absence of an open licence (e.g. Creative Commons), permissions for further reuse of content should be sought from the publisher or author. 


\title{
The importance of customer expectations: An analysis of CSR in container shipping ${ }^{1}$
}

\author{
Lijun Tang ${ }^{2}$ and Victor Gekara ${ }^{3}$
}

\begin{abstract}
Corporate social responsibility (CSR) has been increasingly embraced by corporations to demonstrate effort to reduce negative environmental and social externalities resulting from their business activities. CSR covers a wide range of issues, including environmental concerns, occupational health and safety, local community socialeconomic welfare and workers' rights and welfare issues. Through a detailed content analysis of the CSR related documents on the websites of the top container shipping companies in the world, this paper examines CSR adoption in the container shipping business. The analysis reveals that while institutional pressure plays an important role, shipping companies are more sensitive to market demands and their focus on CSR elements is selective depending on anticipated customer expectations.
\end{abstract}

Keywords: Container shipping, Corporate social responsibility, OHS, seafarers' welfare

\section{Introduction}

It is suggested that the ever-mounting institutional pressure to reduce and internalise negative environmental and social externalities related to corporate activities is leading to increasingly isomorphic corporate social responsibilities (CSR), policies and practices across the world (Matten and Moon 2008). However, as CSR policies may be in conflict with organisational efficiency and compromise profit-maximising objectives, organisations may strategically choose to pay serious attention to some elements of CSR policies while largely ignoring others in practices (Clarkson 1995; Jamali et al. 2017; Meyer 2010). Therefore a commonly known issue with CSR is the disjunction between policies and practices. In this context, Meyer (2010) points out

\footnotetext{
${ }^{1}$ Accepted to be published in Journal of Business Ethics

${ }^{2}$ School of Business, Plymouth University

${ }^{3}$ School of Business IT and Logistics, RMIT University
} 
that, rather than simply dismiss CSR as a window dressing concept, researchers should endeavour to identify the in/consistencies inherent between CSR policies and practices as well as the underlying mechanisms. An adequate understanding of the mechanisms underlying the in/consistencies provides the basis for further improvement in business policies and practices in relation to CSR.

In the past few decades, the shipping industry, like many others, has jumped on the CSR bandwagon with shipping companies increasingly embracing the concept (Yuen et al, 2017). The shipping market is characterised by high volatility, and to remain competitive, shipping companies are known for pursuing aggressive cost-cutting strategies, such as sourcing cheaper labour globally, avoiding seafarer training responsibilities, and lowering ship standards (ILO 2001). Such strategies have often resulted in sub-standard operations, which deteriorate labour standards and are prone to safety and environmental accidents. The tension between the purpose of CSR and fierce market competition in shipping is thus evident, which in turn makes the industry a promising setting to examine CSR policies and practices so as to develop an understanding of the underlying forces.

CSR in shipping in general covers a number of areas, including environmental issues, occupational safety, and workers' rights and welfare issues. The extant literature (e.g. Egels-Zandén 2014; Jamali et al. 2017; Gunningham et al. 2004; 2005) indicates that while organisations may comply with the minimum regulatory standards in some CSR areas, they are more proactive and go beyond compliance in other areas. This insight raises interesting questions: in what CSR areas are shipping companies more proactive and what are the underlying reasons or mechanism? This paper examines these questions through an analysis of the CSR reports and related online documents of the top container shipping companies. Particularly, it interrogates the ways in which container shipping companies define, design and implement CSR programs along what seems to be a reactive-proactive continuum and discusses the underlying mechanisms. In the next section, we review the extant CSR literature and draw out a conceptual framework for the later data analysis and discussion. Following a 
discussion of CSR in shipping and the research method, this paper presents and discusses the findings before drawing out the implications in the concluding section.

\section{CSR policies and practices}

Owing to the multiplicity of aspects and breadth of potential application, CSR is a difficult concept to define. How it is understood and adopted depends on one's view of what social responsibilities are important and for whom. The European Union (EU, $2001,3)$ defines CSR as

a concept whereby companies integrate social and environmental concerns in their business operations and in their interaction with their stakeholders on a voluntary basis.

In a later revision (EU, 2011, 6) it is defined as "the responsibility of enterprises for their impacts on society" thus reducing the emphasis on 'voluntary' and implying an expectation or obligation. Holmes and Watts $(2000,3)$ define CSR as

the commitment of business to contribute to sustainable economic development, working with employees, their families, the local community and society at large to improve their quality of life.

Nevertheless, across all conceptualisations of CSR, the common and recurring defining themes include voluntary actions and proactive initiatives in labour issues and environmental protection, and a philanthropic spirit in community development and wellbeing - the idea that the activities and programs implemented by the organisation are voluntary and proactive, and undertaken for the common social good, alongside the profit-generating core activities.

Why do corporations adopt CSR policies? One major reason suggested in the literature is institutional pressure (Matten and Moon 2008). Increasingly businesses are confronted with intense pressure, including pressure for ethical and responsible conduct with regard to the quality and safety of products and services, respect for human rights in the recruitment and employment of labour, protection of the environment and the support for host community socio-economic welfare. Such 
pressure comes from multiple sources and locations, such as the force of laws and regulations, public opinion and expectations, and views of important institutions such as non-governmental organisations (NGOs) and trade associations (Babiak and Trendafilova 2010; Lozano 2015). For legitimacy and survival, organisations need to conform to these by adopting institutionalized policies, rules and procedures (Meyer and Rowan, 1977). Following DiMaggio and Powell (1983), Matten and Moon (2008) identified three key isomorphic processes, coercive isomorphisms, mimetic processes, and normative pressures, that lead to increasingly standardised and rationalised CSR policies and practices in organisations across the globe. While coercive isomorphisms drive organisations to align their policies and practices with externally codified rules, norms and laws for legitimacy, memetic processes push organisations to adopt what are regarded as best practices or managerial fashions in their organisational fields. Normative pressures, on the other hand, require organisations to embrace standards set by educational and professional authorities (Matten and Moon 2008). As such, it is argued that institutional pressure leads to increased similarities in CSR adoption as well as in the types of CSR policies and practices adopted (Meyer and Rowan, 1977; see also Jamali et al. 2017).

In practice, however, it is often the case that, despite the potential benefits, CSR conflicts with organisational corporate objectives (Haigh and Jones 2006). Following the core principles of corporate capitalism - resource allocation efficiency and profitmaximisation - any activity undertaken by the firm, which has cost implications, must be justified against anticipated profit. The cost minimisation and profit maximisation drive of the firm therefore argues entirely against the notion of voluntary, proactive and philanthropic initiatives, with a cost implication, for the common socio-economic good. According to Friedman (1970), it is not justifiable for corporate executives to engage in activities, with a cost implication, beyond what is required by law and normal dictates of ethical business, for the supposed purpose of satisfying general social interests. Such activity would, in his view, only amount to 'hypocritical window-dressing because it harms the foundation of a free society' unless they, in a significant way, contribute to increasing company profits. 
To manage this conflict, a common strategy is to decouple policy from practice (Meyer and Rowan, 1977). Numerous empirical research findings (e.g., MacLean and Behnam 2010, p. 1499) confirm Friedman's suggestion that in, many cases, CSR adoption mainly serves as 'a form of window dressing, symbolic gestures designed to give the appearance of satisfying regulatory requirements and enhancing external audiences' perceptions of organizational legitimacy while still allowing for business as usual' (see also Aravind and Christmann 2011; Christmann and Taylor 2006; Weaver et al. 1999; Yeung and Mok 2005). Nevertheless, the decoupling practice is constrained by external monitoring and sanctions. According to previous research (Christmann and Taylor 2006; Egels-Zandén 2014; Jamali et al. 2017), on the one hand, increased external demands and monitoring serves to recouple practice and policies over time on CSR issues, and on the other, decoupling practices are likely to persist with CSR issues not subject to strict external vetting and sanctions. This practice of selective decoupling/recoupling suggests the role of coercive pressure in CSR implementation.

There is also evidence that over time corporations may internalise external pressure and normalise CSR practices, which lead to recoupling (Egels-Zandén 2014). Weaver et al. (1999) suggest that commitment from top management is essential for successful CSR implementation. As such, past research has also identified internal motives in CSR adoption, which are, nevertheless, strategic in orientation (Babiak and Trendafilova 2010; Lozano 2015). By voluntarily adopting CSR, a business organisation can enhance its reputation and brand image. In other words, it serves to build reputational capital and provides a competitive advantage (Saeed and Arshad 2012). Also it may help with avoiding risk and managing crisis (Lozano 2015). Research has also shown that in order to preserve corporate reputation and avoid economic risks such as consumer boycott, troubles in acquiring future project permissions, and costly lawsuits, some organizations choose to go beyond merely complying with legal requirements (Gunningham et al. 2004; 2005). Internal motives make CSR a proactive strategy, aiming to satisfy and meet the expectations of various stakeholders so that a firm can garner their support and commitment (Yuen et al. 2017). 
From the literature discussed above, a distinction can be made between reactive and proactive CSR adoptions. Reactive adoption is externally driven, a defensive reaction to external pressure, monitoring and sanctions. When external monitoring is weak, the adopting organisations may decouple CSR policies and practices. By contrast, proactive adoption is internally motivated, a strategy used by the adopting organisations to anticipate and meet demands of stakeholders so as to gain their trust and support. Proactive adoption goes beyond mere compliance. Perhaps more often than not, organisations adopt CSR as a result of both external pressure and internal motives, and their adoptions lie somewhere on the continuum between the reactive and proactive ends. Furthermore, as CSR covers a range of areas, it may be the case that corporations selectively put more resources in and focus on certain areas. In other words, one organisation's adoptions of various CSR areas may lie at various points on the continuum. This insight opens up a new line of enquiry: Where do organisations place various CSR areas on the reactive-proactive continuum? What are the reasons or mechanisms underlying the positional differences? In the next section, we discuss the existing research related to CSR in shipping.

\section{CSR in shipping}

Increasingly shipping companies are adopting and practicing CSR to demonstrate that they take their social responsibilities seriously, and there has been growing attention to CSR research in the shipping industry in recent years (see e.g., Coady and Standberg 2012; European Communities, 2006; Kunnaala et al, 2013; Kontovas and Psaraftis, 2011). The research shows that by adopting CSR policies and programmes shipping companies positively differentiate themselves from their competitors as bestpractice organisations. Consequently, it has been argued that CSR helps with the financial performance of shipping companies (Lu et al. 2009; Yuen et al, 2017). It is also found that CSR in liner shipping enhances customer satisfaction and loyalty and helps maintain strong customer relations, and as such, it is recommended that shipping companies should adopt CSR as a marketing tool (Shin and Thai 2015).

As in other industries, however, there are glaring conflicts, tensions, and contradictions between CSR and shipping operations (Progoulaki and Roe 2011). The shipping 
industry has been described as 'the archetype of unbridled free-market capitalism' (Lilie, 2006: 1) where the quest for efficiency, cost minimization and profit maximization are paramount. For example, to cut operational costs and remain competitive, it is common practice for shipping companies to register their ships in flag of convenience (FOC) countries in order to escape what are considered stringent regulatory regimes, bent on enforcing the highest operating standards in accordance with national and international regulations. By shifting to FOCs, which are popular for their lax approach to regulatory enforcement, the shipping companies are able to recruit seafarers from low-cost labour supply countries. Such cost-cutting strategies have historically led to poor working conditions and weakening labour standards generally. Consequently, research has detailed a history of seafarer exploitation and a failure to uphold acceptable labour standards in terms of working conditions and general welfare of seafarers, particularly on FOC ships (e.g., ITF, 1997). Also, a rise in the number of substandard ships, dubbed 'rust buckets' (Cahill, 1999), following the growth in FOC fleets, led to a series of marine accidents involving catastrophic oil spills between 1970s and 1990s (see, Wonham and Li, 1999; Knudsen and Hassler, 2011). Shipping operations are therefore known to produce a range of negative externalities, such as labour exploitation, health and safety accidents, and marine pollution. The result is that shipping became one of the most stringently regulated and monitored industries through an elaborately structured national and international regulatory regime comprising of national flag-state agencies, regional port-state agencies, international agencies like the International Maritime Organisation (IMO) and the International Labour Organisation (ILO), classification societies, shipping insurance companies, and national and global labour unions, notably the International Transport Workers' Federation (ITF) (Hamad, 2016). For example, the IMO, which is the key global regulator for shipping has developed, and regularly updates, a number of international conventions and codes of business conduct targeting specific areas of regulatory concern, including, environmental pollution (MARPOL), health and safety (SOLAS), and seafarer training and certification (STCW). In 2006, the ILO adopted the Maritime Labour Convention (MLC), which came into force globally in 2013. The aim was to build work and employment protections for seafarers and promote decent work in this sector. It imposes regulatory requirements on issues related to employment conditions, training and career development, and welfare and social security of seafarers. 
Although there are international regulations and enforcement mechanisms on both marine environment and occupational health and safety (OHS) issues, there is a common perception in the industry that oil spill and pollution carries more weight than OHS issues. For example, oil spills are more likely to result in detention and criminalisation of seafarers than safety related accidents. In this respect, Sampson (2016) describes one reputable shipping company who invested heavily in activities related to marine environment protection, even with non-capped budget, but mostly paid lip service to OHS concerns. The justification for this disparity was that environmental concerns were much more stringently monitored and sanctioned than $\mathrm{OHS}$ issues. However, there are a wide range of issues covered by CSR in shipping, including various marine environment issues (such as $\mathrm{CO} 2$ emissions, oil spill, ballast water), OHS, and terms and conditions of seafarers' employment. This paper examines all these, which are also subject to international regulations. CSR elements related to philanthropic community engagement are not subject to international regulations, and therefore are not included in this paper.

\section{Research method}

As adopting CSR requires resources, bigger shipping companies tend to lead the field. In this context, this paper examines the top 15 container shipping companies (as of March 2017). They are the biggest shipping corporations in the world and are therefore resource-rich. Together they control more than 80 per cent of the global container shipping market. Furthermore, more than any other shipping sectors, container shipping companies have highly visible brands. It is expected therefore that they possess both the motivations and resources to adopt and develop CSR to promote and maintain their brand images.

The websites of these 15 container companies were consulted and materials related to CSR were copied and downloaded for analysis. Such materials included details of company initiatives, policies and CSR reports. These companies are: A.P. MollerMaersk Group, Mediterranean Shipping Company (MSC), CMA CGM, China COSCO 
Shipping, Evergreen Marine, Hapag-Lloyd, Hamburg Süd, Yang Ming Marine, Orient Overseas Container Line (OOCL), NYK Line, K Line, Mitsui O.S.K. Lines (MOL), Hyundai Merchant Marine (HMM), United Arab Shipping Company (UASC), and Pacific International Lines (PIL). It needs to be noted that for most of these companies, like Maersk and NYK, liner shipping is just part of their business. Their CSR policies and reports are therefore for the whole group, rather than just the liner sector. Eleven companies produced CSR reports, and for this paper, the most recent ones available were used. These are: Maersk Sustainability Report 2016, MSC Sustainability Report 2016, COSCO Sustainability Report 2014, Evergreen Marine Corporate Social Responsibility Report 2014, Hamburg Süd Sustainability Report 2014/2015, Yang Ming Corporate Social Responsibility Report 2016, Orient Overseas Container Line (OOCL) Sustainability Report 2015, NYK Report 2015, K Line Report 2016, MOL Group Safety, Environment and Social Report 2016, HMM Environmental Report 2017.

The collected data was thematically coded. The codes were not pre-decided but derived from and grounded in the data. These codes were categorised into two groups, environmental issues and human factors. Again these two categories were grounded in data as CSR reports and policies separate the two issues. Human factors include occupational health and safety, seafarers' training and education, and employment related issues. Table 1 shows the identified thematic codes and indicates which element is included in which company's CSR. In the coding process, we read the collected materials closely and identified that while these companies were likely to briefly mention some elements, they tend to provide detailed evidence and examples to show that they were going beyond compliance in other areas.

Insert Table 1 here 


\section{The broad picture}

Out of the 15 companies investigated, two companies, UASC and PIL pay attention to environmental issues only without mentioning human factors. In fact, UASC has not explicitly adopted the concept of CSR, though it promotes on its website and has taken initiatives to protect the environment.

The other thirteen companies have explicitly adopted CSR policies that cover both environmental elements and human factors. Furthermore, eleven of them (excluding H-Lloyd and CMA-CGM) also produce annual CSR reports, which spell out comprehensive CSR strategies and practices. The reports show how the policies or principles are materialised or implemented in practice; describe the actions that have been taken, the outcomes and achievements; and provide details of future plans. In other words, the reports present a comprehensive description of the company CSR strategy from rationale design, implementation, outcome appraisal and future plans.

Although uniformity has not been achieved, the diffusion and popularity of CSR in this sector is evident as the majority of the companies are explicitly adopting CSR and pay attention to both areas. Furthermore, this diffusion seems to continue. For example, MSC recently published the MSC Sustainability Report 2016, its first ever sustainability report, while ten other companies have been doing so for years. It is likely that those companies who have not done so will also follow suit in the future.

An examination of the whole spectrum of identified CSR elements indicates that these elements do not carry equal weight. While some elements are on the CSR spotlight of all the companies, others are under the radar of some companies. Between the two broad areas, environment receives more attention and no company ignores environmental concerns. Even though the majority of them also pay attention to human factors, it is a common feature that they put environmental issues first on their sustainability reports, and HMM produces annual Environmental Report rather than Sustainability or CSR Report. Within each area, similarly, some elements have priority over others, which will be examined in detail in the next two sections. 


\section{The environmental elements}

According to the amount of attention they received, the environmental elements can be group into three tiers. CO2 emissions and energy and fuel efficiency have the top priority and thus belong in the first tier. They are in fact two sides of the same coin, as energy efficiency leads to reduction in $\mathrm{CO} 2$ emissions. Maersk states in its sustainability report 2016:

We are committed to reducing the environmental impact of our operations. We work continually to reduce emissions; dispose of resources responsibly; mitigate pollution and the depletion of natural resources; and prevent our vessels from damaging the marine environment.

On their website they further explain:

In 2014, we launched the Carbon Pact initiative. The goal is to partner with selected customers to overcome one of the most important sustainability challenges facing our industry: Decoupling growth and resource consumption.

When you sign a Carbon Pact with us, we commit to meeting a CO2 reduction target together with you, and we develop a specific plan - tailored to your business - to make it happen. Are you ready for the Carbon Pact challenge?

To reduce $\mathrm{CO} 2$ emissions, all the 15 companies elaborate how they use a wide variety of methods and employ new technologies to reduce fuel consumption. Evergreen, for example, states that apart from the conventional methods, such as slow steaming and weather routing, they have adopted new technologies including 'optimized hull design', 'higher tensile steel', 'rudder bulb design', 'energy-saving bulbous bow', 'electronic controlled engine', and 'variable frequency control seawater pump'. Five companies also mention using renewable energy. MOL, for instance, developed the first car carrier in the world equipped with a solar power generation and storage system, which can provide all the electricity the vessel needs while it is in berth. 
Ballast water management is another element in the first tier and mentioned by all the companies. Surprisingly, oil pollution is not mentioned by all the companies, even though a large amount of bad publicity in the industry is associated with oil spills both accident-related and operational. Together with air pollution (NOx and SOx), ship recycling, general waste management, anti-foul paint, oil pollution are in the second tier of environmental concerns.

Noise control is at the bottom of environmental responsibilities and only five companies briefly mention it. Noise is regulated by the IMO Noise Code, which came into force in 2014. This Code is an amendment to SOLAS, an international convention on safety. It was adopted in the context that high noise levels on ships could affect seafarers' health and compromise safety of the ship. The purpose of the code is to control noise levels in order to reduce seafarers' exposure of damaging noise both in work and living spaces. As such, noise control is more of an OHS issue (human factors) than an environmental one.

\section{Human factors}

Human factors can be divided into two tiers. The top priority is given to health, safety, and education and training. As shipping is a safety critical industry, it is unsurprising that safety related elements receive prominent attention in the human factors. In fact, it is a common practice that companies divide human factors into two distinct groups/issues, health and safety and human resource development. In their sustainability reports, many of the companies dedicate one chapter to elaborate on each of these two issues. Cosco Shipping for example singles out the safety and health element particularly in their annual CSR report for emphasis:

COSCO Group has attached great importance to safety and occupational health work. At the 2014 videoconference on safety production work, it determines eight focuses of safety work to ensure and promote safety production and harmonious development of entire system: Firstly, promote building of safety culture of COSCO Group continuously, and enhance the soft strength for safety development of the enterprise; Secondly, enhance the "red 
line awareness" continuously, and implement the "joint responsibilities of party and political departments and double responsibilities of one post"; Thirdly, implement safety risk evaluation continuously and deepen the inspection of potential risks; Fourthly, strengthen the shore-based tracing and guidance, establish ship-shore mutual-trust mechanism and ensure safety in anti-collision, anti-pirate and anti-typhoon activities; Fifthly, improve the long-term safety mechanism continuously, improve the safety management organizational structure, and strengthen the building of two teams; Sixthly, increase the input to educational and training activities and enhance safety education and training work; Secondly, implement technical guarantee measures continuously and enhance the basic work for engine management; Eighthly, improve the selfevaluation system for safety management continuously, enhance the safety performance evaluation and promote the compliance of safety disciplines; Ninthly, enhance the emergency response management work continuously, promote the building of "up-to-down and inter-linkage" system and elevate the emergency response ability.

Closely related to safety issues is safety training. All of the 13 shipping companies have education and training as a particular focus within the Human Factor CSR area. They claim to have also invested in maritime training facilities, giving detailed accounts on their commitment to, and actions on education, training, and personal development. They talk about their in-house training centres and dedicated maritime education and training (MET) schools/academies/colleges. For example, all three Japanese liners have established MET colleges in the Philippines, while COSCO and OOCL have established training schools in China and Evergreen has a training centre in Taiwan. Furthermore, Hamburg Süd operates two training ships with seasoned instructors providing hands-on training to junior technical and navigational staff, and NYK has six cadet training vessels. Hamburg Süd, NYK, MOL, K Line and OOCL all describe their cadet training programs. Furthermore, for German seafarers,

Hamburg Süd offers junior staff the possibility to train in one of the two dual occupational training options, Bachelor of Science Business Administration and 
Bachelor of Science Wirtschaftsinformatik (Business Informatics), in addition to the classic apprenticeship occupations.

Diversity and gender equality are also in the first tier of human factors, though slightly lower in priority than the elements mentioned above. More than ten companies claim they provide equal opportunity to everybody regardless of race, ethnicity, and gender.

The second tier includes social welfare and social security. Eight companies talk about staff welfare, such as work life balance, annual leave, maternity leave, and paternity leave. These types of leaves, however, are for shore-based staff members. Only four companies, the three Japanese liners and COSCO, report on how they pay attention to seafarers' welfare and family issues. $\mathrm{MOL}$ organises annual family events in the Philippines for their Filipino crew, and COSCO has established 248 contact stations for seafaring families in China. Similarly, NYK holds meetings around the world to facilitate communications between crew members and their families, discussing educational issues for families and cooperation with family associations. $\mathrm{K}$ Line describes its efforts to improve ship board living environment, such as provision of good audio-visual entertainment equipment, expanding means of communicating with families, and training ship's cooks to provide healthy menus.

Also four companies mention social security of their employees. Taiwan and Mainland Chinese companies (Evergreen, Yang Ming, and COSCO) talk about pensions, medical insurance, and other forms of social insurance, as evidence of compliance with the levels of social security required under the MLC 2006. However, these benefits are provided to 'local' and permanent employees. It is clear from their CSR reports that Evergreen and Yang Ming employ overseas seafarers, while COSCO has crew employed through agencies. These seafarers are not employed directly by them, but provided by crew agencies, yet there is no mention of social security benefits for this group of seafarers. 
In fact, all these companies employ seafarers through agencies, and as such their supply of labour often involves global supply chains. There is a large body of literature dealing with how supply chain leverage can be used to improve labour standards (Walters and James 2011; Wright and Kaine 2015). As buyer driven chains are characterised by power asymmetry between larger buyers/clients at the top and smaller suppliers on the bottom, this body of literature suggests that client firms can use their strong bargaining power to pressurise or encourage suppliers to adopt 'high performance' HR strategies (Marchington and Vincent 2004; Scarbrough 2000; Wright and Kaine 2015). As mentioned earlier, liner shipping companies have powerful customers, such as giant global retail companies and manufacturers, and one reason for them to adopt CSR is to satisfy the requirements of these customers who also face pressure from their customer bases. In some cases, however, liner shipping companies sit at the top of their supply chains and have the power to influence their suppliers. In fact, the majority of the companies mention in their CSR reports that they constantly monitor supply chain partners and require them to comply with their CSR policies. Nevertheless, supply chain monitoring seems to predominantly focus on environmental and OHS issues. For example, Hamburg Süd states in its CSR report, 'Hamburg Süd's responsibility does not stop at its own employees, however. The company also expects its suppliers to respect prevailing laws and implement corresponding occupational health and safety measures.' Regarding seafarer labour supply chains, most companies remain silent. Only Maersk admits in their report that:

Recruiting workers and crew through third parties (hiring and employment agencies, local agents or partners), can link A.P. Moller - Maersk to negative human rights impacts if the third party involved does not provide adequate conditions and terms for the workers, for example paying minimum wage, allowing for freedom of organisation or offering social services. A gap in the governance of these relationships needs to be closed.

\section{Discussion}

Although all the companies examined pay attention to CSR issues, such as environmental protection and human factors, they share more similarity in some areas than in others. As a result, some CSR elements are the focus of all the companies, 
while only a few companies marginally mention others. Overall, the environmental area weighs heavier than human factors. This overall picture is in line with the findings of previous research (Sampson 2016).

Nevertheless, oil pollution, which has negatively affected the reputation of shipping more than anything else is not at the centre of liner shipping CSR. Rather, it is CO2 reduction and energy efficiency that has the top priority. Oil pollution, instead, is in the second tier environmental responsibilities with 13 companies referring to it. In human factors, safety, health, and education and training occupy the top spots and are featured in the CSR agendas of 13 companies. Thus, at least in CSR, oil pollution and OHS carry similar weight. In fact, education and training can be seen as an extension of safety issues, as it tends to be mentioned in relation to safety training. Surely, education and training also brings shipping companies other benefits. First, there is a shortage of well-trained and high quality seafarers in the labour market. Setting up colleges and training centres helps with recruitment and retention of seafarers. Second, providing training opportunities serves to enhance company reputation and boost seafarers' commitment. Furthermore, from a traditional perspective of CSR, training as a way of promoting seafarer's careers and empowering them in the labour market would carry a strong message too. Noise control, employee welfare, and social security sit at the bottom of CSR priority. As discussed earlier, all these issues are human factors. Seafarers' welfare and social security, especially that of outsourced seafarers, is by far the least focussed area and companies are more likely to remain silent.

As such, there is a CSR priority continuum of liner shipping. On both ends are $\mathrm{CO} 2$ emissions, ballast water management, noise control, and seafarers' welfare and social security. Interestingly, all these elements came into the regulatory focus only recently and all the relevant regulations came into force in the 2010s. The Energy Efficiency Design Index (EEDI) and the Ship Energy Efficiency Management Plan (SEEMP) entered into force in 2013, The Ballast Water Management Convention in 2017, the Noise Code in 2014, and the MLC in 2013 (which regulates seafarers' welfare and social security issues). Yet, the CSR elements in the environmental area occupy top 
priority for the companies, while the human factors elements are on the bottom, which begs the question of why.

The CSR priority continuum can be matched to the reactive-proactive continuum discussed earlier. As all the issues are regulated and subject to the force of law, to maintain their legitimacy and conduct business, shipping companies at least need to react to these regulations and meet the required standards. Therefore, there is little doubt that these shipping companies comply with all international regulations, although they may not mention the compliance on their CSR. Such compliance can be seen as reactive as it is driven purely by external regulatory pressure and therefore, by definition, not entirely voluntary. Reactive compliance means to comply with the minimum standards, as regulatory pressure only targets what is below the bottom line. As such, it can be said that the container shipping companies largely take a reactive and minimalist compliance approach to seafarer employment related labour issues.

By contrast, their approach to other labour related to issues, such as health and safety, and education and training are more proactive. Together with the environmental elements, they occupy the middle on the continuum. The majority of the companies demonstrate in their CSR that they go beyond the bottom line and aim for better. While the external regulatory pressure is certainly there in relation to these elements, it does not sufficiently explain the 'beyond compliance' attitude. As mentioned earlier, there are also internal motives for CSR, which are more about building reputational capital and risk management (Babiak and Trendafilova 2010; Lozano 2015; Yuen et al, 2017). Container shipping lines provide just-in-time service for customers, and timely delivery is a defining feature of quality service. Any safety or environment incidents can cause ship delays, and any delay would tarnish a shipping line's reputation. Due to various uncertainties, potential hazards and safety incidents cannot be completely eradicated. In this context, shipping lines have incentive to strive for better, invest in environmental issue and $\mathrm{OHS}$, and go beyond minimum compliance, for the purpose of minimising potential risks. Employment related labour issues, however, do not have direct relationships with ship delays and minimum compliance would prevent potential troubles. Furthermore, the beyond compliance approach also serves to build up a 
good reputation with regulatory enforcement organisations. Good reputation and good performance means their ships would be less frequently targeted for inspection (Sampson and Bloor 2007). Conversely, an accident would be likely to result in unwanted inspection, which causes service interruption. As such, the proactive approach in these elements is also internally motivated for gaining reputational capital and managing commercial risks. While the reactive compliance approach is mainly reacting to regulatory pressure, the beyond compliance approach is also a proactive strategy to meet the expectation of customers.

The beyond compliance approach regarding $\mathrm{CO} 2$ emissions reaches the peak level in the sense that all the companies boast their credentials in this area and describe in detail how they go beyond regulatory requirements to improve energy efficiency. What is unique about this element is that it has a more direct link with the product transported. Regarding other environmental and safety elements, they affect customers only when these issues result in ship delays. By contrast, $\mathrm{CO} 2$ emitted during the transportation process would add directly to the total carbon footprint of the product. In the context that carbon footprint may affect the value and marketability of a product, the impact of $\mathrm{CO} 2$ emissions on customers is no longer potential but immediate and real. Previous research on regulatory compliance showed that as customers emphasised carbon efficiency in their logistics chains, container lines perceived it as important to demonstrate the environmental friendliness of their services (Bloor et al. 2013). Thus, it is not very surprising that $\mathrm{CO} 2$ emissions is given top priority by all the companies. Because of the direct link, the benefit of $\mathrm{CO} 2$ emissions reduction can be seen directly by customers and is marketable. Thus, the quote from Maersk about the Carbon Pack reads rather like a marketing message - it is addressed directly to potential customers and persuades them to sign a Carbon Pack.

The discussion above suggests that although CSR is supposed to be proactive and voluntary, in liner shipping it is rather market orientated. It is worth nothing that labour issues in shipping are actually subject to extra institutional pressure, the pressure from ITF. The ITF, a global maritime union association, is seen as a rare example that has developed effective bargaining strategies with ship managers to raise labour standards globally (Lillie 2006). Nevertheless, most shipping liners choose reactive 
compliance to employment related labour issues, as they can only affect shipping customers remotely. By contrast all of the companies take the most proactive approach in $\mathrm{CO} 2$ emissions, which affects customers directly. The market thus dictates CSR.

\section{Conclusion}

From the extant literature (Christmann and Taylor 2006; Egels-Zandén 2014; Jamali et al. 2017; Gunningham et al. 2004; 2005; Lozano 2015; Saeed and Arshad 2012), a CSR adoption continuum can be discerned with one end being reactive adoption and the other proactive adoption. While reactive adoption is driven by external pressure and characterised by minimal compliance, proactive adoption is internally motivated and characterised by going beyond regulatory requirements to gain stakeholders' trust and support. This paper examines CSR adoption in the top container shipping companies by analysing the CSR related documents on their websites. More specifically, it identifies the relative positions of the various CSR elements adopted on the reactive-proactive continuum, and explores the underlying mechanisms of the positional differences.

Overall, these companies are largely reactive with regard to seafarer employment related labour issues, but most proactive in relation to $\mathrm{CO} 2$ emissions. Other labour related issues, such as health and safety, and education and training, together with the environmental elements, occupy the middle position. Noticeably, all these CSR issues are subject to international regulations. Thus, regulatory pressure does not explain the differences in terms of CSR priorities. It can be said that regulations set the bottom line for these reputable and resource rich companies, and that external regulatory pressure does not force them to go beyond the minimum standard. The beyond compliance and proactive approach to the issue of $\mathrm{CO} 2$ emissions is instead internally motivated, aiming to meet customer expectations and provide solutions for customers' problems. Understandably customers would like to choose the best and the most competitive solutions. As a result, companies have to be proactive in anticipation of customer demands, and strive to be the best. 
Thus in shipping, it is the market and customer expectations that hold the key to the alignment between companies' CSR practices and what they should achieve as socially desirable outcomes. Customers like to have less carbon footprint in their transportation; and shipping companies anticipate this demand and go beyond regulatory requirements to cut down on $\mathrm{CO} 2$ emissions. In contrast, seafarer employment is largely invisible to customers, and correspondingly shipping companies only react to the regulatory pressure to keep business as usual. If employment related labour issues are to be taken seriously in CSR, the more (and perhaps the most) effective solution is to make these issues directly linked to customer expectations. For example, health and safety, and seafarers' education and training are also labour related, but they receive more attention and receive more resources and investment from the companies because they have a more direct and bigger impact on the market.

Methodologically, this paper analyses the CSR reports and other CSR related documents on the shipping companies' websites. In the ordinary operation of an organisation such as a business, a large number of documents are produced, including policy reports, performance reports, strategy papers etc. Critically examined these form the blueprint to its organisational behaviour and can provide explanations behind key decisions made and actions taken in the areas of research interest. Thus, analysing the structure, content and focus of the CSR reports of container companies provided us with an important window into the companies' CSR policies and practices. Taken together, these reports revealed the relative un/importance of various CSR elements in the sector and invited an exploration of the mechanisms underlying the differences. Particularly on a topic such as CSR where most company officials are reluctant or unwilling to discuss, with researchers, about discrepancies between expectations, policy proclamations of intent and actual outcomes, systematic analysis of published content as undertaken in this study is a very effective and productive alternative for data collection. Surely, this method can be applied to other sectors and industries as well. It will help develop an understanding of the underlying mechanisms of CSR implementation and provides the basis on which effort can be made to align 
CSR practices with its original purposes - to reduce negative environmental and social externalities (Meyer 2010).

\section{References:}

Aravind, D., \& Christmann, P. (2011). Decoupling of standard implementation from certification: Does quality of ISO 14001 implementation affect facilities' environmental performance? Business Ethics Quarterly, 21(1), 73-102.

Babiak, K., \& Trendafilova, S. (2011). CSR and environmental responsibility: motives and pressures to adopt green management practices. Corporate social responsibility and environmental management, 18(1), 11-24.

Bloor, M., Sampson, H., Baker, S., Walters, D., Dahlgren, K., Wadsworth, E., \& James, P. (2013). Room for manoeuvre? Regulatory compliance in the global shipping industry. Social \& Legal Studies, 22(2), 171-189.

Cahill, R. (1999), Death Ship Scandals. The Guardian. March $17^{\text {th }}$. http://www.cpa.org.au/z-archive/g1999/945ship.htm

Clarkson, M. E. (1995). A stakeholder framework for analyzing and evaluating corporate social performance. Academy of management review, 20(1), 92-117.

Christmann, P., \& Taylor, G. (2006). Firm self-regulation through international certifiable standards: Determinants of symbolic versus substantive implementation. Journal of International Business Studies, 37, 863-878.

Coady, L. and Strandberg, C. (2012). Corporate social responsibility and the shipping industry: a global perspective. In Report prepared for a seminar on CSR activities for the shipping industry hosted by The Nippon Foundation.

DiMaggio, P., \& Powell, W. (1983). The iron cage revisited: Institutional isomorphism and collective rationality in organizational fields. American Sociological Review, 48(2), 147-160.

Egels-Zandén, N. (2014). Revisiting supplier compliance with MNC codes of conduct: Recoupling policy and practice at Chinese toy suppliers. Journal of Business Ethics, 119(1), 59-75. 
EU (2001) Green paper: Promoting a European framework for corporate social responsibility. europa.eu/rapid/press-release_DOC-01-9_en.pdf

EU (2011) A renewed EU strategy 2011-14 for Corporate Social Responsibility. http://www.europarl.europa.eu/meetdocs/2009_2014/documents/com/com_com (2011)0681_/com_com(2011)0681_en.pdf

Friedman, $\quad$ M. (1970). A $\quad$ Freidman Doctrine.

http://www.nytimes.com/1970/09/13/archives/a-friedman-doctrine-the-socialresponsibility-of-business-is-to.html

Gunningham, N., Kagan, R.A. and Thornton, D. (2004) Social License and Environmental Protection: Why Businesses Go beyond Compliance. Law \& Social Inquiry 29(2): 307-341.

Gunningham, N., Thornton, D. and Kagan, R.A. (2004) Motivating Management: Corporate Compliance in Environmental Protection. Law \& Policy 27(2): 289-316.

Haigh, M., \& Jones, M. T. (2006). The drivers of corporate social responsibility: a critical review. In GBER 2006: Proceedings of the 2006 Global Business and Economics Research conference (pp. 1-8). GBER.

Harvey, F. (2016). Shipping industry criticised for failure to reach carbon emissions deal. The Guardian. https://www.theguardian.com/environment/2016/oct/28/shipping-industry-failsagreement-cap-carbon-emissions

Holme, R. and Watts, P. (2000) Corporate social responsibility: Making good business sense.

http://www.ceads.org.ar/downloads/Making\%20good\%20business\%20sense.p $\underline{\mathrm{df}}$

Jamali, D., Lund-Thomsen, P., \& Khara, N. (2017). CSR institutionalized myths in developing countries: An imminent threat of selective decoupling. Business \& Society, 56(3), 454-486.

Knudsen O. F. and Hassler B. (2011) IMO legislation and its implementation: Accident risk, vessel deficiencies and national administrative practices. Marine Policy 35:201-207

Kontovas, C. A., \& Psaraftis, H. N. (2011). The link between economy and environment in the post-crisis era: lessons learned from slow 
steaming. International Journal of Decision Sciences, Risk and Management, 3(3-4), 311-326.

Kunnaala, V., Rasi, M., \& Storgård, J. (2013). Corporate Social Responsibility and Shipping Views of Baltic Sea Shipping Companies on the Benefits of Responsibility. $\quad$ http://www.doria.fi/bitstream/handle/10024/94151/A70Corporate_Social_Responsibility_and_Shipping_pdf.pdf?sequence=2

Li, K. X., \& Wonham, J. (1999). Who is safe and who is at risk: a study of 20 -yearrecord on accident total loss in different flags. Maritime Policy \& Management, 26(2), 137-144.

Lillie, N. (2006). A global union for global workers: Collective bargaining and regulatory politics in maritime shipping. London: Taylor \& Francis.

Lozano, R. (2015). A holistic perspective on corporate sustainability drivers. Corporate Social Responsibility and Environmental Management, 22(1), 32-44.

Lu, C. S., Lin, C. C., \& Tu, C. J. (2009). Corporate social responsibility and organisational performance in container shipping. International Journal of Logistics: Research and Applications, 12(2), 119-132.

MacLean, T.L. \& Behnam, M. (2010). The dangers of decoupling: the relationship between compliance programs, legitimacy perceptions, and institutionalized misconduct. Academy of Management Journal, 53(6): 1499-1520.

Marchington M, Vincent S (2004) Analysing the influence of institutional, organizational and interpersonal forces in shaping inter-organizational relations. Journal of Management Studies 41(6): 1029-1056.

Matten, D., \& Moon, J. (2008). "Implicit" and "explicit" CSR: A conceptual framework for a comparative understanding of corporate social responsibility. Academy of management Review, 33(2), 404-424.

Meyer, J. W. (2010). World society, institutional theories, and the actor. Annual review of sociology, 36, 1-20.

Meyer, J. W., \& Rowan, B. (1977). Institutionalized organizations: Formal structure as myth and ceremony. American journal of sociology, 83(2), 340-363.

Nautilus (2012) Seafarers transporting Fairtrade produce need better treatment, says Nautilus. $\quad$ https://nautilusint.org/en/what-we-say/nautilus-news/seafarerstransporting-fair-trade-produce-need-better-treatment,-says-nautilus/ 
Progoulaki, M., \& Roe, M. (2011). Dealing with multicultural human resources in a socially responsible manner: a focus on the maritime industry. WMU journal of maritime affairs, 10(1), 7-23.

Saeed, M. M., \& Arshad, F. (2012). Corporate social responsibility as a source of competitive advantage: The mediating role of social capital and reputational capital. Journal of Database Marketing \& Customer Strategy Management, 19(4), 219-232.

Sampson, H. (2016) "Seabirds Matter More Than Us!" Understanding the Complex Exercise of CSR in the Global Shipping Industry, Journal of Sustainable Mobility, 3(2):101-119.

Sampson, H., \& Bloor, M. (2007). When Jack gets out of the box: the problems of regulating a global industry. Sociology, 41(3), 551-569.

Scarbrough H (2000) The HR implications of supply chain relationships. Human Resource Management Journal 10(1): 5-17.

Shin, Y., \& Thai, V. V. (2015). The impact of corporate social responsibility on customer satisfaction, relationship maintenance and loyalty in the shipping industry. Corporate Social Responsibility and Environmental Management, 22(6), 381-392.

Walters D and James P (2011) What motives employers to establish preventive management arrangement? Safety Science 49 (7): 988-994.

Weaver, G. R., Trevino, L. K., \& Cochran, P. L. (1999). Integrated and decoupled corporate social performance: Management commitments, external pressures, and corporate ethics. Academy of Management Journal, 42: 539-552.

Wright, C. F., \& Kaine, S. (2015). Supply chains, production networks and the employment relationship. Journal of industrial Relations, 57(4), pp.483-501.

Yeung, G., \& Mok, V. (2005). What are the impacts of implementing ISOs on the competitiveness of manufacturing industry in China? Journal of World Business, 40, 139-157. 
Yuen, K. F., Thai, V. V., \& Wong, Y. D. (2017). Corporate social responsibility and classical competitive strategies of maritime transport firms: A contingency-fit perspective. Transportation Research Part A: Policy and Practice, 98, 1-13. 
Table 1: Environmental Issues and Human Factors included in Container Shipping CSR

\begin{tabular}{|c|c|c|c|c|c|c|c|c|c|c|c|c|c|c|c|c|c|}
\hline \multicolumn{2}{|l|}{ CSR Concern } & \multirow[b]{2}{*}{ Total } & \multicolumn{15}{|c|}{ Shipping Company } \\
\hline & & & APM & MSC & CMA-CGM & NYK & MOL & K-Line & OOCL & HMM & cosco & H-Lloyd & H-Sud & Evergreen & YMM & PIL & UASC \\
\hline \multirow{14}{*}{ Environment } & CO2 emissions & 15 & $\checkmark$ & $\checkmark$ & $\checkmark$ & $\checkmark$ & $\checkmark$ & $\checkmark$ & $\checkmark$ & $\checkmark$ & $\checkmark$ & $\checkmark$ & $\checkmark$ & $\checkmark$ & $\checkmark$ & $\checkmark$ & $\checkmark$ \\
\hline & Energy and Fuel Efficiency & 15 & $\checkmark$ & $\checkmark$ & $\checkmark$ & $\checkmark$ & $\checkmark$ & $\checkmark$ & $\checkmark$ & $\checkmark$ & $\checkmark$ & $\checkmark$ & $\checkmark$ & $\checkmark$ & $\checkmark$ & $\checkmark$ & $\checkmark$ \\
\hline & Renewable Energy & 5 & & & & $\checkmark$ & $\checkmark$ & $\checkmark$ & $\checkmark$ & & & & $\checkmark$ & & & & \\
\hline & Ballast water & 15 & $\checkmark$ & $\checkmark$ & $\checkmark$ & $\checkmark$ & $\checkmark$ & $\checkmark$ & $\checkmark$ & $\checkmark$ & $\checkmark$ & $\checkmark$ & $\checkmark$ & $\checkmark$ & $\checkmark$ & $\checkmark$ & $\checkmark$ \\
\hline & & & & & & & & & & & & & & & & & \\
\hline & SOx Emissions & 13 & $\checkmark$ & & $\checkmark$ & $\checkmark$ & $\checkmark$ & $\checkmark$ & $\checkmark$ & $\checkmark$ & $\checkmark$ & $\checkmark$ & $\checkmark$ & $\checkmark$ & $\checkmark$ & $\checkmark$ & \\
\hline & NOx Emissions & 11 & $\checkmark$ & & & $\checkmark$ & $\checkmark$ & $\checkmark$ & $\checkmark$ & $\checkmark$ & $\checkmark$ & & $\checkmark$ & $\checkmark$ & $\checkmark$ & $\checkmark$ & \\
\hline & Oil pollution & 13 & $\checkmark$ & & $\checkmark$ & $\checkmark$ & $\checkmark$ & $\checkmark$ & $\checkmark$ & $\checkmark$ & $\checkmark$ & $\checkmark$ & $\checkmark$ & $\checkmark$ & $\checkmark$ & $\checkmark$ & \\
\hline & Ship demolition & 13 & $\checkmark$ & $\checkmark$ & $\checkmark$ & $\checkmark$ & $\checkmark$ & $\checkmark$ & $\checkmark$ & $\checkmark$ & $\checkmark$ & $\checkmark$ & $\checkmark$ & $\checkmark$ & & & $\checkmark$ \\
\hline & General waste & 12 & $\checkmark$ & & $\checkmark$ & $\checkmark$ & $\checkmark$ & $\checkmark$ & $\checkmark$ & $\checkmark$ & $\checkmark$ & $\checkmark$ & $\checkmark$ & $\checkmark$ & $\checkmark$ & & \\
\hline & Anti-Fouling paint & 11 & & $\checkmark$ & $\checkmark$ & & $\checkmark$ & $\checkmark$ & $\checkmark$ & $\checkmark$ & $\checkmark$ & & & $\checkmark$ & $\checkmark$ & $\checkmark$ & $\checkmark$ \\
\hline & & & & & & & & & & & & & & & & & \\
\hline & Noise Control & 5 & & & & & & & $\checkmark$ & $\checkmark$ & $\checkmark$ & $\checkmark$ & $\checkmark$ & & & & \\
\hline & & & & & & & & & & & & & & & & & \\
\hline \multirow[t]{8}{*}{ Human Factor } & Staff Safety & 13 & $\checkmark$ & $\checkmark$ & $\checkmark$ & $\checkmark$ & $\checkmark$ & $\checkmark$ & $\checkmark$ & $\checkmark$ & $\checkmark$ & $\checkmark$ & $\checkmark$ & $\checkmark$ & $\checkmark$ & & \\
\hline & Staff Health & 13 & $\checkmark$ & $\checkmark$ & $\checkmark$ & $\checkmark$ & $\checkmark$ & $\checkmark$ & $\checkmark$ & $\checkmark$ & $\checkmark$ & & $\checkmark$ & $\checkmark$ & $\checkmark$ & & \\
\hline & Staff Training & 13 & $\checkmark$ & $\checkmark$ & $\checkmark$ & $\checkmark$ & $\checkmark$ & $\checkmark$ & $\checkmark$ & $\checkmark$ & $\checkmark$ & & $\checkmark$ & $\checkmark$ & $\checkmark$ & & \\
\hline & Diversity & 11 & $\checkmark$ & $\checkmark$ & $\checkmark$ & $\checkmark$ & $\checkmark$ & $\checkmark$ & $\checkmark$ & & & $\checkmark$ & $\checkmark$ & $\checkmark$ & $\checkmark$ & & \\
\hline & Gender Equality at work & 11 & & $\checkmark$ & $\checkmark$ & $\checkmark$ & $\checkmark$ & $\checkmark$ & $\checkmark$ & & $\checkmark$ & $\checkmark$ & $\checkmark$ & $\checkmark$ & $\checkmark$ & & \\
\hline & & & & & & & & & & & & & & & & & \\
\hline & Social security & 4 & $\checkmark$ & & & & & & $\checkmark$ & & $\checkmark$ & & & $\checkmark$ & & & \\
\hline & Social welfare (maternity leave etc) & 8 & $\checkmark$ & & & $\checkmark$ & $\checkmark$ & $\checkmark$ & $\checkmark$ & & $\checkmark$ & & & $\checkmark$ & $\checkmark$ & & \\
\hline
\end{tabular}

